\title{
100 Years of Cinema
}

\author{
By Jan Uhde
}

Spring 1995 Issue of KINEMA

\section{YEARS OF CINEMA: REMEMBERING BOLESLAW MATUSZEWSKI}

In 1995, the eyes of the film world seem to look back upon that celebrated December day a century ago, when the first moving images of Louis and Auguste Lumière flickered on the screen in the Indian Salon inside the Grand Café on the Boulevard des Capucines in Paris. But there was another man who lived in that same time and place, a long-forgotten visionary without whom we might have very little to celebrate today: Boleslaw Matuszewski.

Already in 1898, Matuszewski publicly voiced the idea that films embody values transcending their primary purpose and that the life of a film should not end with its last theatrical presentation. This Polish cameraman, a Lumière employee, proposed that a Motion Pictures Historical Depository (Dépôt de cinématographie historique) be created, thus acknowledging the significance of preservation of filmed material for posterity.

At that time, moving images were seen by most people as an ephemeral novelty, a technical curiosity soon to be forgotten. Their potential could only be guessed at, and by no means were they considered art. As there was only a handful of films in existence then, all of them brand new, any discussion as to collecting, preserving, and cataloguing them would certainly seem to be a theoretical one. And to raise it, would certainly require more than an ordinary imagination. Even Louis Lumière himself lacked his cinematographer's vision. It is Lumière who is considered to be the author of the notorious phrase "Film is an invention without a future."

Under these circumstances, Matuszewski's suggestions were well ahead of their time. Indeed, it is difficult not to be astonished at his extraordinary farsightedness. His preoccupation with film preservation was, according to the French film archivist and historian Raymond Borde, precipitated by a revelatory incident. In 1897, after assuming the position of photographer to Tsar Nicholas II, he used the Lumières' Cinématographe to record the official visit to St. Petersburg, of the French President Félix Faure. After the visit, the German Chancellor Bismarck accused Faure of not baring his head before the Russian flag on his disembarkation. However, this accusation could be confidently rejected -- and Bismarck's malevolent maneuver exposed -thanks to the proof provided in black-and-white by Matuszewski's documentary.

A year later, Matuszewski published two brochures, A New Source of History, soon followed by Animated Photography. The latter can in fact be considered one of the first theoretical texts on film ever written. In the former, Matuszewski proposed establishment of a "cinematographic museum or depository . . . to be given the same official existence, the same access as to other archives . . . It should have a museum section, library department, and an archive vault." (Une nouvelle source de l'histoire, Paris: Imprimerie Noizette et Cie, p.10.) It was chiefly the factual film he had in mind, and no wonder, as the production of the time knew practically nothing else. (The first narrative pictures were introduced by Georges Méliès in the Spring of 1897).

Matuszewski suggested the film archives be sub-divided into sections reflecting the existing cinema types; these would include for example the film genre we now call the filmed theatre, motion picture police archive and others; the latter would, he thought, help in identification of criminals. His proposal envisaged a public archive that would provide access to its holdings through open projections, as is now customary in many cinematheques all over the world.

The notion of depository law, an idea of supreme importance in the history of film preservation, was also fathered by Matuszewski. This concept maintained that films "ought to be conserved as elements of the patrimony," that they belong to the national cultural heritage. Consequently, the production (or the distribution) companies would be obliged to surrender a print of any film produced (or distributed) in the country, if requested for deposit by the National Archives. In France, the depository law became reality only in 1977. In the United States a federal legislation to safeguard the national film heritage is only a few years old. In many countries it is still considered too revolutionary. 


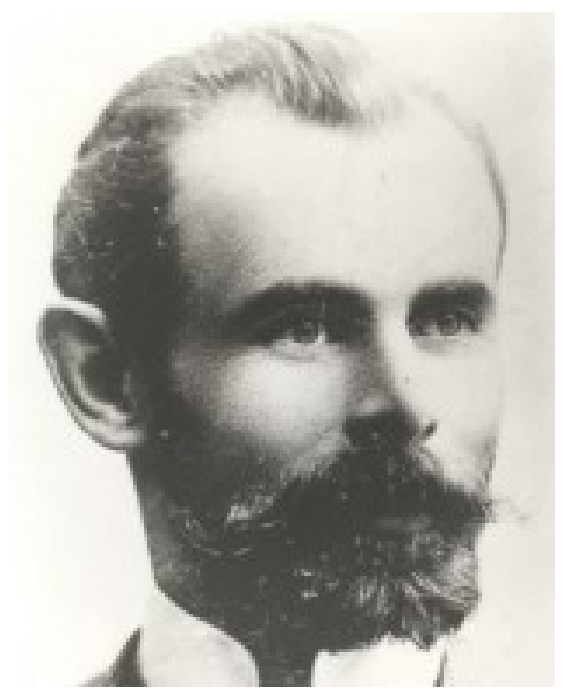

Figure 1: Boleslaw Matuszewski

Matuszewski also proposed the publication of a periodical with an international editorial board, where questions of film preservation could be discussed. After a few enthusiastic articles in the daily press, however, Matuszewski's suggestions quickly fell into oblivion. It is not even known where and when he died.

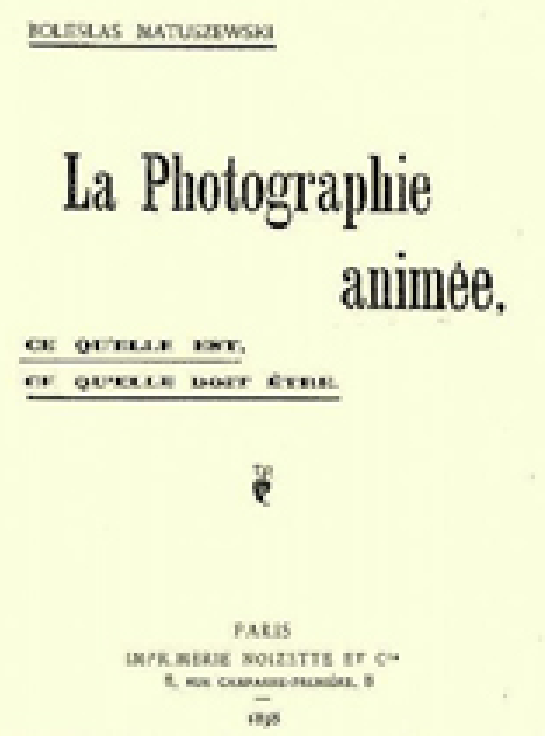

Figure 2: Matuszewski's 1898 book cover

\section{Author Information}

Jan UHDE is Professor Emer. (Film Studies) at the University of Waterloo, Ontario, Canada. Born in Brno, Czech Republic. Graduated (MA) from the Faculty of Arts, Masaryk University, Brno; PhD received at the University of Waterloo, Ontario, Canada. He taught at the University of Waterloo (1970-2012) where he founded a General and Honours BA program in Film Studies at the Department of Fine Arts.

Publications: Latent Images: Film in Singapore Second edition, with Yvonne Ng Uhde (Ridge Books, National University Press of Singapore, 2010); Latent Images: Film in Singapore, with Yvonne Ng Uhde (Oxford 
University Press, 2000); Latent Images: Film in Singapore CD-ROM (2003, co-author); Vision and Persistence: Twenty Years of the Ontario Film Institute (University of Waterloo Press, 1990) and Ontario Film Institute Programming Activities Index 1969-1989 (Toronto: Ontario Science Centre, 1990). He co-edited the Place in Space: Human Culture in Landscape (Proceedings from the Second International Conference of the Working Group "Culture and Landscape" of the International Association of Landscape Ecology, Pudoc Scientific Publishers, Wageningen, Holland, 1993). Jan Uhde has published articles and reviews in several countries (including Canada, USA, Germany, Italy), participated in international juries at film festivals and presented papers at international conferences in North America and Europe. In 1998/99, he was a visiting researcher at the School for Film and Media Studies, Ngee Ann Polytechnic, Singapore.

His professional and research interests focus on Singapore cinema; the identification and distancing mechanisms of the film viewer; the non-authored modifications and manipulation of films; and specific aspects of film history, including the Central European cinema.

He founded KINEMA in 1993. 